\title{
Local population persistence as a pre-condition for large-scale dispersal of Idotea metallica (Crustacea, Isopoda) on drifting habitat patches
}

\author{
Lars Gutow \\ Alfred Wegener Institute for Polar and Marine Research, Biologische Anstalt Helgoland, Box 180, \\ 27483 Helgoland, Germany \\ E-mail:lgutow@awi-bremerhaven.de
}

Key words: Idotea metallica, extinction, dispersal, habitat destruction, food quality

\begin{abstract}
Idotea metallica establishes self-sustaining populations exclusively on objects drifting at the sea surface. Largescale transport of drift material with surface currents results in an efficient dispersal of the species. Two types of drifting objects are utilised (biotic and abiotic), providing quite different conditions of life. Ephemeral biotic substrata (mainly uprooted macroalgae) may be used for transport and food, however, resulting habitat destruction from feeding must be a major threat for local population persistence of I. metallica. Abiotic substrata or wood represent efficient vectors for long-distance dispersal due to their resistance to biodegradation, but do not provide food for this herbivorous species. In laboratory experiments, the spatially-limited conditions of drifting substrata were simulated in microcosms. Idotea metallica established persistent populations on both types of substrata. On abiotic substrata, however, where the animals were fed only on Artemia larvae, high variations in density and a reduced intrinsic rate of population growth increased the risk of population extinction. Idotea metallica avoids habitat destruction by limited feeding on macroalgae. In contrast, the coastally distributed congener Idotea baltica destroyed algal habitats by feeding about 10 times faster than I. metallica.
\end{abstract}

\section{Introduction}

Idotea metallica Bosc maintains persistent populations in the Mediterranean Sea (Dow \& Menzies, 1958; Abelló \& Frankland, 1997) and off the east coast of North America (Locke \& Corey, 1989). Individuals occur in the entire North Atlantic (Naylor, 1957; Tully \& McGrath, 1987; Davoult et al., 1999; Franke et al., 1999), and occasionally in the South Atlantic (Moreira, 1972) and the Pacific (Van der Baan \& Holthuis, 1969). Idotea metallica disperses efficiently as self-sustaining local populations on drift material (Gutow \& Franke, 2003). The persistence of these often abiotic drifting objects enables even species with low natural dispersal capacity to be passively transported over long distances with surface currents (Barnes, 2002).

Depending on the substrata, inhabiting animals are exposed to fundamentally different conditions. Due to their resistance to biodegradation, persistent objects (plastic bottles, remains of fishing nets and wood) represent efficient vectors for long-distance dispersal. Ephemeral substrata (mainly drifting, uprooted macroalgae), however, are exposed to a high risk of destruction particularly by the feeding activities of inhabiting animals. On drifting macroalgae, isopods feed on both their substrata and zooplankton from the surrounding water, whereas on persistent abiotic substrata, plant food is limited (if not entirely absent).

For I. metallica, efficiency of dispersal is linked to the persistence of local populations. The present paper, therefore, examines the risks of local population extinction for I. metallica through investigations on demographic stochasticity under laboratory conditions and environmental aspects such as food quality and risk of habitat destruction. 


\section{Materials and methods}

All experiments were conducted at a constant temperature of $16^{\circ} \mathrm{C}$ and an artificial 16:8 light-dark cycle.

\section{Effect of food quality on population dynamics}

Microcosm experiments were carried out in 51 vessels with aerated seawater. One experimental group was run with $100 \mathrm{~g}$ of the brown alga Fucus vesiculosus L. as the biotic substratum. In the other group, $100 \mathrm{~g}$ of a plastic fishing net served as a persistent non-biotic substratum. The vessels were each stocked initially with 20 animals (10 males and 10 females) of about 45 days old. Each treatment was run in 5 replicates over 24 weeks. Freshly-hatched Artemia nauplii served as food and were offered ad libitum. Water was exchanged once to twice a week. Every 14 days, animals in the vessels were counted. At the same time, algae were replaced by fresh fronds but the nets remained unchanged.

The intrinsic rates of population growth $(r)$ were calculated for the initial period of exponential growth (week 0-6) using the following equation:

$$
r=\frac{\ln N_{2}-\ln N_{1}}{t_{2}-t_{1}},
$$

where $N=$ the number of animals and $t=$ time (in weeks). In order to record not simply reproductive rates of initially-introduced animals but to include mortality as antagonist of reproduction over an appropriate period into the calculation, population densities were estimated as 3-point running means.

\section{Rate of substratum destruction}

To determine the rate of substratum destruction, two sets of experiments were carried out with I. metallica and results compared with the coastally distributed, benthic congener Idotea baltica (Pallas). Ten adult animals (5 males and 5 females) were each placed into $20 \times 20 \times 6 \mathrm{~cm}$ plastic boxes. The boxes were supplied with 11 of aerated seawater and a branch of Fucus vesiculosus or Ascophyllum nodosum (L.) (the two dominant drift algae species in the North Sea), respectively. The water was exchanged daily and hatched juveniles and bitten off pieces of algae were removed. Animals that died during the experimental period were replaced. The fresh weight of the algal branch was measured every second day to $0.1 \mathrm{~g}$. Five

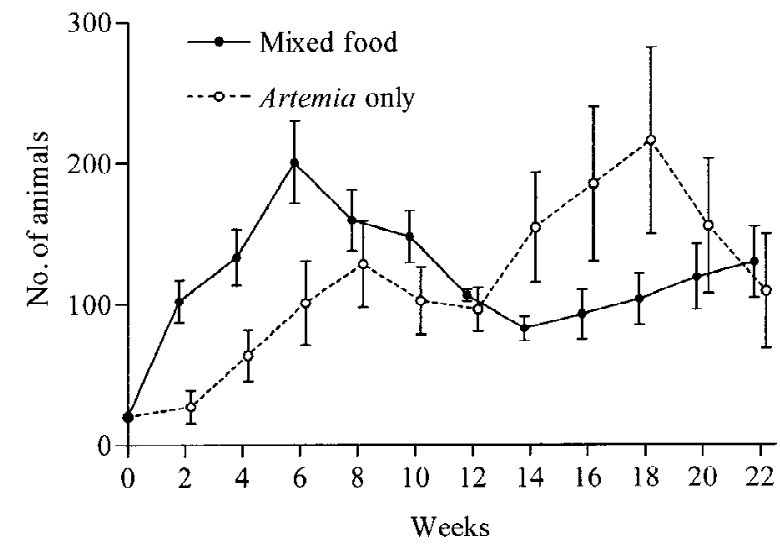

Figure 1. Number of animals of Idotea metallica in microcosms under different food conditions. Error bars denote standard error $(n=5)$.

experimental units (replicates) each were run for 10 days with and without Artemia larvae as an additional source of animal food.

\section{Results}

\section{Effect of food quality on population dynamics}

ldotea metallica developed persistent populations under both feeding conditions (Fig. 1). None of the experimental populations went extinct within 24 weeks. An initial overshoot in population density was followed by a period of marked oscillations around the value of the capacity starting in week 12 for each treatment. During the initial growth phase (week 0-6), populations grew significantly faster (Student's $t$-test, $P=0.029)$ under mixed food conditions $(r=0.38 \pm$ $\left.0.06^{*} \mathrm{wk}^{-1}\right)$ than without plant food $\left(r=0.24 \pm 0.10^{*}\right.$ $\mathrm{wk}^{-1}$ ). Food quality had no effect (Student's $t$-test, $P=0.255$ ) on the capacities of the microcosms (calculated as mean population densities from week 12 on) for I. metallica (mixed food: $105.6 \pm 30.2$ ind.; without algae: $152.6 \pm 80.4$ ind.). Under mixed food conditions, oscillations (expressed as standard deviation of log-transformed population densities) were weaker $(0.30 \pm 0.18)$ than in the absence of plant food $(0,68 \pm 0.31)$ (Student's $t$-test, $P<0.05)$.

\section{Rate of substratum destruction}

Both species caused a significant ( $F$-test, $P$ always $<$ 0.01) loss of algal fresh weight (Fig. 2). A 3-factorial ANOVA (comparing the slopes of linear regression 
Table 1. Results of the 3 -factorial ANOVA on the rates of habitat destruction $\left(\mathrm{g} *\right.$ ind $^{-1} * \mathrm{~d}^{-1}$ )

\begin{tabular}{|c|c|c|c|c|c|c|}
\hline & Source of variation & df & SS & MS & $F$ & $P$ value \\
\hline \multirow[t]{4}{*}{ (a) } & Main effects & & & & & \\
\hline & Factor 1 (isopod species) & 1 & 0.0185 & 0.0185 & 123.907 & $<0.001$ \\
\hline & Factor 2 (algae species) & 1 & 0.0003 & 0.0003 & 1.954 & 0.172 \\
\hline & Factor 3 (presence of Artemia) & 1 & 0.0008 & 0.0008 & 5.308 & 0.028 \\
\hline \multirow[t]{4}{*}{ (b) } & First-order interaction & & & & & \\
\hline & Factors $1 \times 2$ & 1 & 0.0000 & 0.0000 & 0.268 & 0.608 \\
\hline & Factors $1 \times 3$ & 1 & 0.0010 & 0.0011 & 7.109 & 0.012 \\
\hline & Factors $2 \times 3$ & 1 & 0.0001 & 0.0001 & 0.564 & 0.458 \\
\hline \multirow[t]{4}{*}{ (c) } & Second-order interaction & & & & & \\
\hline & Factors $1 \times 2 \times 3$ & 1 & 0.0002 & 0.0002 & 1.357 & 0.253 \\
\hline & Within subgroups (error) & 32 & 0.0048 & 0.0002 & & \\
\hline & Total & 39 & 0.0257 & 0.0007 & & \\
\hline
\end{tabular}
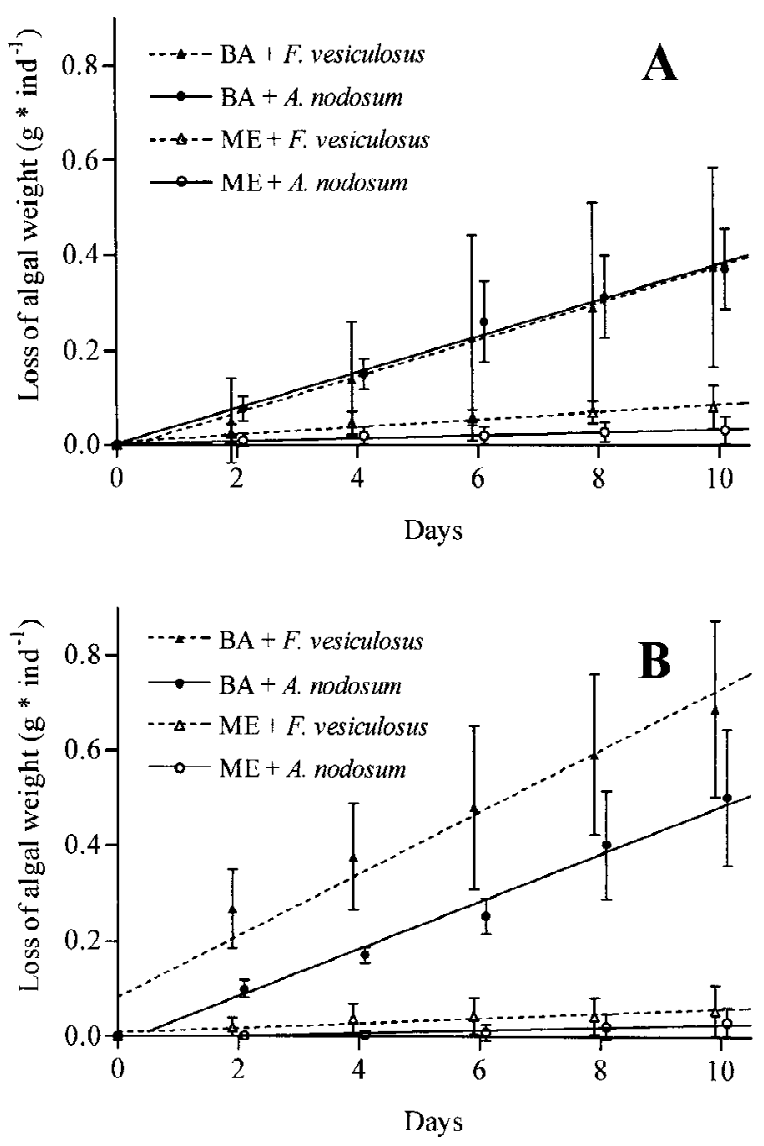

Figure 2. Rate of habitat destruction plotted as cumulative loss of algal freshweight with (A) and without (B) Artemia as additional source of food (ME = Idotea metallica $; \mathrm{BA}=$ Idotea baltica $)$. Error bars denote standard error $(n=5)$. in Fig. 2) revealed that I. baltica reduced algal fresh weight faster than I. metallica (Table 1). For each species, the rate of habitat destruction was independent of algal species. In I. metallica, habitat destruction proved to be independent of the presence/absence of additional zooplanktonic food while in I. baltica it increased in its absence. As a result, I. baltica reduced algal fresh weight about 6 times faster than I. metallica when Artemia nauplii were available (0.038 \pm 0.016 and $0.006 \pm 0.004 \mathrm{~g}^{*}$ ind $^{-1 *} \mathrm{~d}^{-1}$, respectively), but about 14 times faster when this food was absent $\left(0.057 \pm 0.018\right.$ and $0.004 \pm 0.004 \mathrm{~g}^{*}$ ind $^{-1 *} \mathrm{~d}^{-1}$, respectively).

\section{Discussion}

Idotea metallica disperses as self sustaining local populations on drifting objects. Thus, the efficiency of dispersal is linked closely to population persistence on these objects. In general, animal populations face two sources of local extinction: an external risk caused by the variability of the environment, and an internal risk based on demographic stochasticity (Caughley, 1994).

Among environmental threats, habitat destruction is by far the most serious one. For I. metallica, destruction of a local habitat patch would lead to the complete extinction of a local population. Habitat destruction is most serious in biotic substrata such as drifting macroalgae. Present experiments revealed that I. metallica had limited feeding on macroalgae, indicating that its habitat is not likely to be destroyed quickly by feed- 
ing. Its congener I. baltica, however, destroyed macroalgal patches about 10 times faster, thus reducing the persistence time of macroalgal patches dramatically (especially when the high densities of I. baltica on drifting algae are considered). Franke et al. (1999) found up to about 85 specimens of I. baltica (considering only animals longer than $10 \mathrm{~mm}$ ) per kg drift algae, while I. metallica occurred with a maximum density of 1 animal per $\mathrm{kg}$. For I. baltica, rapid loss of algal substratum is not a problem as this coastally distributed species (Naylor, 1955) may assume a benthic life style after patch destruction (Locke \& Corey, 1989). Even if additional planktonic animal food is absent, I. metallica hardly feeds on macroalgae, emphasizing the importance of patch persistence for this species.

Even though abiotic objects represent more persistent substrata, in microcosms with mixed feeding conditions, additional plant food increased the intrinsic rate of population increase $(r)$ of $I$. metallica significantly for the initial phase of exponential population growth (week 0-6). Furthermore, population size varied stronger around the capacity (week 12-24) in the absence of plant food. Both a lower population growth rate and a higher variability in population size increase the stochastic risk of population extinction (Hanski, 1999).

In conclusion, although abiotic substrata represent a persistent habitat for I. metallica they do not provide optimum food supply.

\section{References}

Abelló, P. \& R. J. Frankland, 1997. Population characteristics of the neustonic isopod Idotea metallica (Crustacea, Isopoda, Idoteidae) in the western Mediterranean (June 1993). Sci. mar. 61: 409-414.
Barnes, D. K. A., 2002. Invasions by marine life on plastic debris. Nature 416: 808-809.

Caughley, G., 1994. Directions in conservation biology. J. anim. Ecol. 63: 215-244.

Davoult, D., J.-M. Dewarumez, C. Luczak \& A. Migné, 1999. Nouvelles signalisations d'espèces benthiques sur les côtes francaises de la Manche orientale et de la Mer du Nord. Cah. Biol. mar. 40: $121-127$.

Dow, T. G. \& R. J. Menzies, 1958. The pelagic isopod Idotea metallica in the Mediterranean. Pubbl. Staz. Zool. Napoli 30: 330-336.

Franke, H.-D., L. Gutow \& M. Janke, 1999. The recent arrival of the oceanic isopod Idotea metallica Bosc off Helgoland (German Bight, North Sea): an indication of a warming trend in the North Sea? Helgoländer Meeresunters. 52: 347-357.

Gutow, L. \& H.-D. Franke, 2003. Metapopulation structure of the marine isopod Idotea metallica, a species associated with drifting habitat patches. Helgol. mar. Res. 56: 259-264.

Hanski, I., 1999. Metapopulation Ecology. Oxford University Press, New York. 266 pp.

Locke, A. \& S. Corey, 1989. Amphipods, isopods, and surface currents: a case for passive dispersal in the Bay of Fundy, Canada. J. Plankton Res. 11: 419-430.

Moreira, P. S., 1972. Species of marine Isopoda (Crustacea, Peracarida) from Southern Brazil. Bolm. Inst. Oceanogr., S Paulo 21: 163-179.

Naylor, E., 1955. The ecological distribution of british species of Idotea (Isopoda). J. anim. Ecol. 24: 255-269.

Naylor, E., 1957. The occurrence of Idotea metallica in British waters. J. mar. biol. Ass. U.K. 36: 599-602.

Tully, O. \& D. McGrath, 1987. The status of Idotea metallica Bosc (Isopoda) in Irish waters. Ir. Nat. J. 22: 190-192.

Van der Baan, S. M. \& L. B. Holthuis, 1969. On the occurrence if Isopoda in the surface plankton in the North Sea near the lightship “Texel”. Neth. J. Sea Res. 4: 354-363. 